\title{
COMMUNITY RESPONSE OF NONTARGET SPECIES TO HERBICIDE APPLICATION AND REMOVAL OF THE NONINDIGENOUS INVADER POTENTILLA RECTA L.
}

\author{
R.L. Sheley ${ }^{1}$ and M. Kirk Denny ${ }^{2}$
}

\begin{abstract}
Our main objective was to improve understanding of herbicide effects on community dynamics to refine the use of technology and advance the development of ecologically based weed management strategies. We hypothesized that native grasslands would exhibit reductions in culturally sensitive forb cover, biomass, and density relative to the rate of application of selective rangeland herbicides, and that hand-removal of sulfur cinquefoil (Potentilla recta $\mathrm{L}$.) would increase indigenous species cover, biomass, density, species richness, and diversity. Treatments consisted of 3 rates each of 2,4-D + clopyralid $\left(0.28 \mathrm{~kg}\right.$ ai $\cdot \mathrm{ha}^{-1}+0.0532 \mathrm{~kg}$ ai $\cdot \mathrm{ha}^{-1}, 0.56 \mathrm{~kg}$ ai $\cdot \mathrm{ha}^{-1}+0.1064 \mathrm{~kg}$ ai $\cdot \mathrm{ha}^{-1}, 0.84$ $\mathrm{kg}$ ai $\cdot \mathrm{ha}^{-1}+0.1596 \mathrm{~kg}$ ai $\left.\cdot \mathrm{ha}^{-1}\right) ; 2,4-\mathrm{D}$ amine $\left(0.532 \mathrm{~kg}\right.$ ai $\cdot \mathrm{ha}^{-1}, 1.064 \mathrm{~kg}$ ai $\cdot \mathrm{ha}^{-1}, 1.596 \mathrm{~kg}$ ai $\cdot$ ha $\left.{ }^{-1}\right)$; metsulfuron $\left(0.0042 \mathrm{~kg}\right.$ ai $\cdot \mathrm{ha}^{-1}, 0.021 \mathrm{~kg}$ ai $\cdot \mathrm{ha}^{-1}, 0.032 \mathrm{~kg}$ ai $\left.\cdot \mathrm{ha}^{-1}\right)$; picloram $\left(0.14 \mathrm{~kg}\right.$ ai $\cdot \mathrm{ha}^{-1}, 0.28 \mathrm{~kg}$ ai $\cdot \mathrm{ha}^{-1}, 0.56 \mathrm{~kg}$ ai $\left.\cdot \mathrm{ha}^{-1}\right)$; and clopyralid $\left(0.05025 \mathrm{~kg}\right.$ ai $\cdot \mathrm{ha}^{-1}, 0.21 \mathrm{~kg}$ ai $\cdot \mathrm{ha}^{-1}, 0.42 \mathrm{~kg}$ ai $\left.\cdot \mathrm{ha}^{-1}\right)$. This experiment was replicated 3 times at 2 lateseral, noninfested sites in southeastern Montana. In a companion study, sulfur cinquefoil was removed adjacent to paired nonremoved controls in 5 replicates at 2 sites in $1-\mathrm{m}^{2}$ plots for 2 growing seasons. Canopy cover, density, and biomass were collected 24 months after initial treatment at all sites. Indigenous perennial grass cover and biomass increased with herbicide application; however, picloram, metsulfuron, and clopyralid reduced native forb density at 1 site, and picloram reduced forb cover at both sites regardless of rate. Effects of herbicides on species richness or diversity were not detected. Hand-removing sulfur cinquefoil increased total plant richness, especially that of native forbs. Restoring species richness and diversity may be difficult using selective broadleaf herbicides because key functional groups, such as forbs, appear to be at risk.
\end{abstract}

Key words: species richness, species diversity, herbicides, forbs, native plants, Potentilla recta.

For centuries Great Plains natives relied upon their knowledge of the indigenous flora and fauna for their livelihood. Settlement of this region brought nonindigenous plant species, some of which now inhabit millions of hectares, and immediate disturbance to the Native Americans' system (Sheley and Petroff 1999). Some species of specific concern include spotted knapweed (Centaurea maculosa Lam.), Russian knapweed (Acroptilon repens [L.] DC.), leafy spurge (Euphorbia esula L.), and sulfur cinquefoil (Potentilla recta L.). Evidence suggests these invaders decrease indigenous species diversity, richness, and biomass (Tyser and Key 1988, Belcher and Wilson 1989, Kedzie-Webb et al. 2001). In addition, invasions may facilitate degradation of ecosystem structure and function (Vitousek 1986, Randall 1996) by altering critical processes such as nutrient cycles, hydrologic cycles, and energy flow (Vitousek and Walker 1986, Lacey et al. 1989).
The displacement of indigenous species is a cultural and ecological concern for plant managers throughout this region. Managing diverse indigenous plant assemblages not only increases community tolerance of stress events, like drought (Tilman 1996), but it may also improve resistance to invasion by nonindigenous species (Elton 1958, Rejmanek 1996, Levine and D'Antonio 1999, Pokorny 2002). Herbicides have been used as the primary tool for controlling invasive plants (Hamaker et al. 1967, Griffith and Lacey 1991). However, there is little evidence that repeated herbicide use alone at landscape scales has consistently displaced invaders or restored the structure and function of native plant communities. The longterm impact of herbicide use on nontarget native forbs, although not well tested, is assumed to be substantial (Harris and Cranston 1979, Cuda et al. 1989). Rice et al. (1997) found minimal herbicide impacts to native forbs over 
time, after a single application; however, periodic retreatment was necessary to control spotted knapweed. Treatments applied frequently enough to truncate new seed production and exhaust the seed bank of nonindigenous species could presumably require several years, if not decades of treatment to accomplish (Griffith and Lacey 1991). This process could produce a remnant community low in richness and diversity, which subsequently could be functionally altered and/or made more susceptible to reinvasion by nonindigenous species.

Our main objective was to improve understanding of herbicide effects on community dynamics in order to refine the use of technology and advance the development of ecologically based weed management strategies (Sheley et al. 1996). Specifically, this study was implemented to quantify herbicide impacts on plant community composition. The study was also designed to identify herbicide and rate combinations that are effective on nonindigenous weeds and have the least negative impact on indigenous forbs. The 2nd objective of this study was to quantify coexisting indigenous species response to the removal of a nonindigenous invader without herbicide present. The removal would better characterize the impacts of sulfur cinquefoil on indigenous plant communities, while improving understanding of the potential reassembly of an invaded community (Lockwood 1997). We hypothesized that native grasslands would exhibit reductions in culturally sensitive forb cover, biomass, and density relative to the application rates of selective rangeland herbicides. We also hypothesized that removal of the invader sulfur cinquefoil would increase indigenous species cover, biomass, density, species richness, and diversity.

\section{Methods}

\section{Study Sites}

Field studies at White Buffalo and Paddy Creek were conducted to quantify impacts of herbicidal control on native plants of the Northern Cheyenne Reservation in southeastern Montana from 1998 to 2000. The 1st site was established near the head of White Buffalo drainage $16.5 \mathrm{~km}$ south of Lame Deer, Montana $\left(45^{\circ} 28^{\prime} \mathrm{N}, 106^{\circ} 35^{\prime} \mathrm{W}\right)$. Annual temperatures at White Buffalo range from $37^{\circ}$ to $-37^{\circ} \mathrm{C}$, with an average frost-free period of 108 days (USDANRCS 1996). At White Buffalo mean precipi- tation is $432 \mathrm{~mm}$ at the 1250-m-elevation site. Precipitation over the year is bimodal with peaks occurring in spring and autumn. The soil is a Bitton-Twin Creek-Ringling, dry complex with slopes ranging from $5 \%$ to $10 \%$ at this site. Bitton and Twin Creek loams comprise $65 \%$ of the complex. White Buffalo is classified as a Festuca idahoensis / Agropyron smithii habitat type similar to that de- scribed by Mueggler and Stewart (1980) for western Montana. Idaho fescue (Festuca idahoensis Elmer) dominates the site and had canopy cover of about $40 \%$ in 1999 and 2000. Other infrequently established grasses include Kentucky bluegrass (Poa pratensis L.), needle-and-thread (Hesperostipa comata [Trin. \& Rupr.] Barkworth), and smooth brome (Bromus inermis Leyss.). Predominant forbs include western yarrow (Achillea millefolium L.), cudweed sagewort (Artemisia ludoviciana Nutt.), many-flowered aster (Aster ericoides L.), and slimflower scurfpea (Psoralidium tenuiflorum [Pursh.] Rydb.)

The 2 nd site is located in the upper reaches of the Paddy Creek drainage $18 \mathrm{~km}$ southeast of Busby, Montana $\left(45^{\circ} 28^{\prime} \mathrm{N}, 106^{\circ} 40^{\prime} \mathrm{W}\right)$. This site has an $8 \%-15 \%$ northeasterly slope, and the soil at Paddy Creek is Shambo-Doney-Cabba loams at $40 \%, 30 \%$, and $15 \%$, respectively (USDA-NRCS 1996). Elevation is $1220 \mathrm{~m}$ at Paddy Creek, which receives an average of 432 mm of bimodal precipitation annually. The frostfree duration averages 112 days. Native species include western wheatgrass (12\% canopy cover) associated with western yarrow and cudweed sagewort. Kentucky bluegrass (19\% canopy cover) and black medic (Medicago lupulina L.) were the most common nonnative species in 1999.

In addition, we established 2 Northern Cheyenne Reservation study sites, Muddy Creek and Skunk Creek, to quantify native plant recovery in the absence of herbicide by hand-removing sulfur cinquefoil from a native plant community weekly from 1999 to 2000 . The 1st site is located near the confluence of Muddy Creek and Rosebud Creek $\left(45^{\circ} 36^{\prime} \mathrm{N}, 106^{\circ} 44^{\prime} \mathrm{W}\right)$. Muddy Creek is located $10 \mathrm{~km}$ west of Lame Deer, Montana. Muddy Creek soil is a Yamac loam (USDA-NRCS 1996), slope ranges from $2 \%$ to $8 \%$, and annual precipitation is about $305 \mathrm{~mm}$. Muddy Creek has a frost-free period of 115-130 days. In 1999, when the study was initiated, the site was dominated by sulfur 
cinquefoil with a mean canopy cover of $43 \%$ and 170 plants $\cdot \mathrm{m}^{-2}$. Kentucky bluegrass comprised $21 \%$ of total grass canopy cover $(26 \%$ at Muddy Creek). Other forbs include manyflowered aster, scarlet gaura (Gaura coccinea Nutt. ex Pursh.), and alyssum (Alyssum L.).

The 2nd site, Skunk Creek, is located $16.5 \mathrm{~km}$ south of Busby, Montana $\left(45^{\circ} 23^{\prime} \mathrm{N}, 106^{\circ} 58^{\prime} \mathrm{W}\right)$. Skunk Creek soil is a Shambo loam with a 2\%-8\% northern slope (USDA-NRCS 1996). Annual precipitation is about $432 \mathrm{~mm}$ per year with a frost-free period of 112 days. Annual temperatures range from $37^{\circ}$ to $-37^{\circ} \mathrm{C}$. Sulfur cinquefoil was the dominant species in 1999, with a mean canopy cover of $35 \%$ and mean density of 145 plants $\cdot \mathrm{m}^{-2}$ for nonremoved plots. Primary grass species include sideoats grama (Bouteloua curtipendula [Michx.] Torr.), which had 95 tillers $\cdot \mathrm{m}^{-2}$, and Kentucky bluegrass, which had a mean density of 102 tillers $\cdot \mathrm{m}^{-2}$. Other common forbs include many-flowered aster and cudweed sagewort.

\section{Experimental Design}

White Buffalo and Paddy Creek study sites consisted of 15 treatments ( 5 herbicides, 3 rates, and a nontreated control) applied to $2 \times 10-\mathrm{m}$ plots on 24 June 1998. Treatments were replicated 3 times in a randomized complete block design at each site due to suspected environmental gradients caused by slope. Treatments consisted of 3 rates each of 2,4-D + clopyralid respectively $\left(0.28 \mathrm{~kg}\right.$ ai $\cdot \mathrm{ha}^{-1}+0.0532 \mathrm{~kg}$ ai . $\mathrm{ha}^{-1}, 0.56 \mathrm{~kg}$ ai $\cdot \mathrm{ha}^{-1}+0.1064 \mathrm{~kg}$ ai $\cdot \mathrm{ha}^{-1}$, $0.84 \mathrm{~kg}$ ai $\cdot \mathrm{ha}^{-1}+0.1596 \mathrm{~kg}$ ai $\cdot \mathrm{ha}^{-1}$ ); 2,4-D amine $\left(0.532 \mathrm{~kg}\right.$ ai $\cdot \mathrm{ha}^{-1}, 1.064 \mathrm{~kg}$ ai $\cdot \mathrm{ha}^{-1}$, $1.596 \mathrm{~kg}$ ai $\left.\cdot \mathrm{ha}^{-1}\right)$; metsulfuron $(0.0042 \mathrm{~kg}$ ai . $\mathrm{ha}^{-1}, 0.021 \mathrm{~kg}$ ai $\cdot \mathrm{ha}^{-1}, 0.032 \mathrm{~kg}$ ai $\left.\cdot \mathrm{ha}^{-1}\right)$; picloram $\left(0.14 \mathrm{~kg}\right.$ ai $\cdot \mathrm{ha}^{-1}, 0.28 \mathrm{~kg}$ ai $\cdot \mathrm{ha}^{-1}$, $\left.0.56 \mathrm{~kg} \mathrm{ai} \cdot \mathrm{ha}^{-1}\right)$; and clopyralid $(0.05025 \mathrm{~kg}$ ai . $\mathrm{ha}^{-1}, 0.21 \mathrm{~kg}$ ai $\cdot \mathrm{ha}^{-1}, 0.42 \mathrm{~kg}$ ai $\left.\cdot \mathrm{ha}^{-1}\right)$. For ease of presentation, the treatments are labeled "low," "medium," or "high" rates for each herbicide in the Results section. This does not imply that the treatment has any relationship to field application rates. Plots were handsprayed in 1998 using a $\mathrm{CO}_{2}$ backpack spray unit applying $130 \mathrm{~L} \cdot \mathrm{ha}^{-1}$ total spray volume. Conditions were overcast with heavy dew, wind $<5 \mathrm{mph}$, and temperature of $18.3^{\circ} \mathrm{C}$.

Muddy Creek and Skunk Creek sulfur cinquefoil treatments, removed and nonremoved, were replicated 5 times in a completely randomized design at each site in $1-\mathrm{m}^{2}$ plots.
Due to the small plot sizes, an environmental gradient was not seen, and the experiment was completely randomized. Sulfur cinquefoil removal treatments were accomplished by handpulling $100 \%$ of the sulfur cinquefoil twice each month during June, July, and August for 2 growing seasons.

\section{Sampling}

Sampling began at White Buffalo, Paddy Creek, Muddy Creek, and Skunk Creek in 1999. Canopy cover was estimated on a per species basis for all species present in 3 randomly placed $20 \times 50$-cm frames within each plot at White Buffalo and Paddy Creek. Canopy cover at Muddy and Skunk Creeks was collected by the same procedure with a randomly placed frame in each plot. To minimize plot disturbance, we collected only canopy cover within each plot in 1999. We collected canopy cover, density, and biomass data 24 months after initial treatment at both sites. We recorded grass density at White Buffalo and Paddy Creek by counting all tillers of each species present within 3 randomly placed $20 \times 50$-cm frames. Grass density at Muddy Creek and Skunk Creek was counted from a single randomly placed 20 $\times 50$-cm frame in each plot. Simultaneously, forb density was collected by counting the number of individuals of each species within the frame. Biomass was collected by clipping and sorting individual species at ground level from a randomly placed $0.44-\mathrm{m}^{2}$ hoop at all 4 locations. We air-dried samples at $60^{\circ} \mathrm{C}$ for 48 hours before weighing.

\section{Data Analysis}

White Buffalo and Paddy Creek data were initially combined and analyzed as a split plot in time (treatments $=$ whole plots, year $=$ subplots) for species richness. Analysis of variance (ANOVA) revealed that White Buffalo and Paddy Creek significantly differed in species richness, which prompted site-specific analysis. We analyzed treatment effects on diversity, richness, canopy cover, biomass, and density. ANOVA was used on the average of the 3 subsamples to test the hypothesis that native forb species respond variably to different rates of rangeland herbicides (SAS 1990).

First, at White Buffalo and Paddy Creek, we used ANOVA for a split plot in time (treatments $=$ whole plots, year $=$ subplots) to determine effects of herbicide, rate, herbicide * rate, year, 
year * herbicide, year * rate, and year * herbicide * rate on canopy cover, diversity (Shannon-Weiner $\mathrm{H}^{\prime}=-\sum \mathrm{P}_{\mathrm{i}} \cdot \log \left[\mathrm{P}_{\mathrm{i}}\right]$ ), and species richness where year was the split plot in the ANOVA. Herbicide, rate, and herbicide* rate were the whole plots. Block * herbicide * rate was used as the whole plot error term. Year and all interactions with year were the split plots. The model error was used as the split plot error term.

Second, at White Buffalo and Paddy Creek, we used ANOVA for a randomized complete block to determine effects of herbicide, rate, and herbicide * rate on biomass and density for grasses and forbs. These dependent variables were analyzed first as groups and then individually by species. Block * herbicide * rate was used as the error term for these analyses. When treatment or interaction was significant at the $P \leq 0.05$ level, mean separations were achieved using Fisher's protected Least Significant Difference (LSD; Peterson 1985), with the exception of western yarrow cover at White Buffalo which is presented at the $P \leq 0.06$ level to illustrate a similar trend between sites.

For Muddy Creek and Skunk Creek, sites were combined, and we used a completely randomized ANOVA design, split for year effects on canopy cover, to determine effects of site, removal treatment, year, and year * removal on diversity (Shannon-Weiner) and canopy cover for grasses and forbs separately. Sulfur cinquefoil was not included in the forb group. We conducted $t$ tests to detect differences in richness, density, and biomass in the perennial grass group as well as the indigenous forb group. Richness between grasses and forbs was not tested.

\section{RESULTS}

\section{Hand-removing Sulfur Cinquefoil}

Hand-removing sulfur cinquefoil did not affect the cover or biomass of perennial grasses. Pulling sulfur cinquefoil increased nontarget indigenous forb cover $(P<0.02)$, but did not affect forb density or biomass. Total forb cover was about $5 \%$ in the nonpulled control and increased to around $12 \%$ after sulfur cinquefoil removal.

Shannon-Weiner diversity was not affected by hand-removal. Hand-removing sulfur cinquefoil increased species richness from about 2.9 species to about $4.1(P=0.01)$. The increase occurred predominantly within the indigenous forb group. Forb richness increased from 1.3 to 2.4 species $(P<0.01)$.

\section{Herbicide Effect on Nontarget Plants}

Perennial grass COVER.-Although perennial grass density at White Buffalo was not influenced by any herbicide treatments, the impact of herbicides on total perennial grass cover (indigenous and nonindigenous grasses) depended on the interaction of herbicide and rate of application $(P<0.01)$. Total perennial grass cover in the nontreated control was $52 \%$ (Table 1). Clopyralid applied at $0.42 \mathrm{~kg}$ ai $\cdot \mathrm{ha}^{-1}$; clopyralid at $0.0532 \mathrm{~kg}$ ai $\cdot \mathrm{ha}^{-1}$ plus $0.28 \mathrm{~kg}$ ai . $\mathrm{ha}^{-1}$ of 2,4-D; and metsulfuron at $0.0042 \mathrm{~kg}$ ai . $\mathrm{ha}^{-1}$ increased total perennial grass canopy cover from $51 \%$ to $63 \%, 61 \%$, and $63 \%$, respectively. All other treatments produced cover similar to that of the control. Herbicides did not influence Idaho fescue cover at White Buffalo.

At Paddy Creek total perennial grass $(P<$ $0.01)$ and Kentucky bluegrass $(P<0.01)$ cover differed between years. In 1999 mean perennial grass canopy cover was $38 \%$ and increased to $50 \%$ two years after treatment. In 1999 Kentucky bluegrass had $23 \%$ canopy cover, which increased to $33 \%$ in 2000 . Total perennial grass $\left(P=0.03 ; \operatorname{LSD}_{(0.05)}=6 \%\right)$ and Kentucky bluegrass $\left(P=0.02 ; \operatorname{LSD}_{(0.05)}=6 \%\right)$ cover also depended upon the herbicide applied. Across all rates, picloram increased perennial grass cover to $54 \%$, which was $13 \%$ higher than that of the control. Picloram also increased Kentucky bluegrass cover from $23 \%$ to $38 \%$. All other herbicide main effects and interactions did not significantly differ.

PERENNIAL GRASS BIOMASS.-Effects of herbicides on perennial grass biomass depended upon their rate at White Buffalo $(P=0.03)$. Total grass biomass in the nontreated control was $779 \mathrm{~kg} \cdot \mathrm{ha}^{-1}$ (Table 2). Clopyralid applied at $0.16 \mathrm{~kg}$ ai $\cdot \mathrm{ha}^{-1}$ plus $2,4-\mathrm{D}$ at $0.84 \mathrm{~kg}$ ai . $\mathrm{ha}^{-1}$ increased perennial grass biomass to $1701 \mathrm{~kg} \cdot \mathrm{ha}^{-1}$. Metsulfuron at $0.02 \mathrm{~kg}$ ai $\cdot \mathrm{ha}^{-1}$ produced $1768 \mathrm{~kg} \cdot \mathrm{ha}^{-1}$ of perennial grass. Similarly, 2,4-D applied at $0.532 \mathrm{~kg}$ ai $\cdot \mathrm{ha}^{-1}$ yielded $1573 \mathrm{~kg} \cdot \mathrm{ha}^{-1}$. Picloram, applied at 0.56 $\mathrm{kg}$ ai $\cdot \mathrm{ha}^{-1}$, yielded about 2.5 times more perennial grass than that of the control. Other 
TABLE 1. Interaction of herbicides and rate $^{1}$ on perennial grass cover at White Buffalo.

\begin{tabular}{lccc}
\hline \multirow{2}{*}{ Herbicide } & \multicolumn{3}{c}{ Perennial grass cover (\%) } \\
\cline { 2 - 4 } & Low & Medium & High \\
\hline Control & 52 & 52 & 52 \\
Clopyralid + 2,4-D & 61 & 47 & 51 \\
2,4-D & 57 & 52 & 48 \\
Metsulfuron & 63 & 49 & 56 \\
Picloram & 51 & 47 & 51 \\
Clopyralid & 47 & 51 & 63 \\
& \multicolumn{4}{c}{$\operatorname{LSD}_{(0.05)}=8 \%$} \\
\hline
\end{tabular}

${ }^{1}$ Treatments consist of 3 rates each of 2,4-D + clopyralid $\left(0.28 \mathrm{~kg}\right.$ ai $\cdot \mathrm{ha}^{-1}+$ $0.0532 \mathrm{~kg}$ ai $\cdot \mathrm{ha}^{-1}, 0.56 \mathrm{~kg}$ ai $+0.1064 \mathrm{~kg}$ ai $\cdot \mathrm{ha}^{-1}, 0.84 \mathrm{~kg}$ ai $\cdot \mathrm{ha}^{-1}+0.1596$ $\mathrm{kg}$ ai $\left.\cdot \mathrm{ha}^{-1}\right) ; 2,4-\mathrm{D}$ amine $\left(0.532,1.064\right.$, and $1.596 \mathrm{~kg}$ ai $\left.\cdot \mathrm{ha}^{-1}\right)$; metsulfuron $\left(0.0042,0.021\right.$, and $0.032 \mathrm{~kg}$ ai $\left.\cdot \mathrm{ha}^{-1}\right)$; picloram $(0.14,0.28$, and $0.56 \mathrm{~kg}$ ai $\cdot$ $\left.\mathrm{ha}^{-1}\right)$; and clopyralid $\left(0.05025,0.21\right.$, and $\left.0.42 \mathrm{~kg}^{\mathrm{ai}} \cdot \mathrm{ha}^{-1}\right)$. For ease of presentation, the treatments are labeled as low, medium, or high rates for each herbicide.

herbicide by rate combinations did not significantly alter biomass from that of the control. We also analyzed biomass of individual species, but we detected no significant differences at White Buffalo.

Effects of herbicides on perennial grass biomass depended upon their rate at Paddy Creek $(P=0.03)$. Clopyralid at $0.1064 \mathrm{~kg}$ ai . $\mathrm{ha}^{-1}$ plus $2,4-\mathrm{D}$ at $0.56 \mathrm{~kg}$ ai $\cdot \mathrm{ha}^{-1}$ increased perennial grass biomass to $1512 \mathrm{~kg} \cdot \mathrm{ha}^{-1}$ over that of the control, which was $726 \mathrm{~kg} \cdot \mathrm{ha}^{-1}$ (Table 2). Picloram at $0.56 \mathrm{~kg}$ ai $\cdot \mathrm{ha}^{-1}$ yielded nearly 2 times as much perennial grass as that of the control at Paddy Creek.

At Paddy Creek, effects of herbicides on Kentucky bluegrass biomass depended upon their rate $\left(P=0.03 ; \operatorname{LSD}_{(0.05)}=208 \mathrm{~kg} \cdot \mathrm{ha}^{-1}\right)$. The control produced about $405 \mathrm{~kg} \cdot \mathrm{ha}^{-1}$. Although no rate of clopyralid alone affected Kentucky bluegrass biomass, clopyralid plus $2,4-\mathrm{D}$ applied at $0.56 \mathrm{~kg}$ ai $\cdot \mathrm{ha}^{-1}+0.1064 \mathrm{~kg}$ ai $\cdot \mathrm{ha}^{-1}, 2,4-\mathrm{D}$ at $1.596 \mathrm{~kg}$ ai $\cdot \mathrm{ha}^{-1}$, or picloram at $0.56 \mathrm{~kg}$ ai $\cdot \mathrm{ha}^{-1}$ increased the grass biomass to about $1150 \mathrm{~kg} \cdot \mathrm{ha}^{-1}$. Clopyralid plus 2,4-D applied at $0.84 \mathrm{~kg}$ ai $\cdot \mathrm{ha}^{-1}+$ $0.1596 \mathrm{~kg}$ ai $\cdot \mathrm{ha}^{-1}$ or metsulfuron at $0.021 \mathrm{~kg}$ ai $\cdot \mathrm{ha}^{-1}$ increased Kentucky bluegrass by about $225 \mathrm{~kg} \cdot \mathrm{ha}^{-1}$ over that of the control. All other herbicides and rates were similar to that of the nontreated plots.

Forb COVER.-Total forb cover depended upon year at White Buffalo $(P=0.02)$. Total forb cover was about $28 \%$ in 1999 , the 1st year after treatment, and it decreased to $24 \%$ in 2000. Total forb cover was also influenced by herbicide $(P=0.03)$. Without herbicides, forb cover was $28 \%$ (Table 3 ). Across all rates, total forb cover ranged from $31 \%$ following application of clopyralid plus 2,4-D to $19 \%$ after applying picloram. All herbicide treatments produced more forb cover than picloram and were similar to that of the control at White Buffalo.

Analysis of forb cover by species indicated that western yarrow cover was dependent upon the interaction between year following treatment and the rate of herbicide applied at White Buffalo $(P=0.02)$. In 1999 the highest rate of any herbicide reduced yarrow from $5 \%$ cover in the control to $2 \%$ cover (Table 4). Two years after treatment yarrow cover increased to $4 \%$ in the control and $7 \%$ after being treated with the highest rate of any herbicide at this site.

Year $(P=0.01)$ following treatment or herbicide $(P=0.01)$ main effects influenced forb cover at Paddy Creek. In 1999 total forb cover was $50 \%$, but decreased to $35 \%$ in 2000 at this site. Picloram reduced forb cover from $45 \%$ in the control to $27 \%\left(\operatorname{LSD}_{(0.05)}=9 \%\right)$. All other herbicides produced similar cover to that of the control at Paddy Creek.

Herbicide $(P=0.01)$ or rate $(P=0.01)$ main effects influenced western yarrow cover at Paddy Creek. The application of 2,4-D increased yarrow cover from $13 \%$ in the untreated control to $20 \%\left(\operatorname{LSD}_{(0.05)}=5 \%\right)$. Picloram reduced yarrow to $9 \%$, which was below that of clopyralid plus 2,4-D (16\%); 2,4-D alone (20\%); or clopyralid alone (17\%). Low and moderate rates of any herbicide increased yarrow cover from $13 \%$ in the control to $18 \%$ $\left(\operatorname{LSD}_{(0.05)}=4 \%\right)$. High rates decreased yarrow cover to $10 \%$, which was similar to that of the control at Paddy Creek.

The influence of herbicides on American vetch cover depended on their rate at Paddy Creek $(P=0.04)$. When treated with $2,4-\mathrm{D}$ at $1.064 \mathrm{~kg}$ ai $\cdot \mathrm{ha}^{-1}$ or metsulfuron at $0.0042 \mathrm{~kg}$ ai $\cdot \mathrm{ha}^{-1}$, vetch cover increased from $2 \%$ in the control to $4 \%$ (Table 5). Picloram at $0.56 \mathrm{~kg}$ ai . $\mathrm{ha}^{-1}$ reduced vetch cover to a trace $(<1 \%)$. Vetch response to other herbicides by rate combinations was not detected.

The influence of herbicide on black medic cover depended upon the year after treatment at Paddy Creek $\left(P=0.01 ; \operatorname{LSD}_{(0.05)}=7 \%\right)$. In 1999, 2,4-D decreased medic cover from $28 \%$ (control) to $20 \%$, but this herbicide did not 
TABLE 2. Interaction of herbicides and rate $^{1}$ on perennial grass biomass at White Buffalo and Paddy Creek.

\begin{tabular}{|c|c|c|c|c|c|c|}
\hline \multirow[b]{3}{*}{ Herbicide } & \multicolumn{6}{|c|}{ Perennial grass biomass $\left(\mathrm{kg} \cdot \mathrm{ha}^{-1}\right)$} \\
\hline & \multicolumn{3}{|c|}{ White Buffalo } & \multicolumn{3}{|c|}{ Paddy Creek } \\
\hline & Low & Medium & High & Low & Medium & High \\
\hline Control & 778.5 & 778.5 & 778.5 & 726.2 & 726.2 & 726.2 \\
\hline Clopyralid+2,4-D & 821.9 & 1320.6 & 1700.5 & 514.5 & 1512.4 & 1093.0 \\
\hline $2,4-\mathrm{D}$ & 1572.9 & 919.1 & 820.3 & 968.0 & 543.4 & 1308.7 \\
\hline Metsulfuron & 883.8 & 1767.8 & 1270.4 & 379.4 & 1066.0 & 571.1 \\
\hline Picloram & 1118.9 & 885.2 & 1953.5 & 119.4 & 684.2 & 1442.2 \\
\hline \multirow[t]{2}{*}{ Clopyralid } & 1127.3 & 899.7 & 1157.8 & 730.1 & 610.3 & 641.5 \\
\hline & \multicolumn{3}{|c|}{$\mathrm{LSD}_{(0.05)}=646 \mathrm{~kg} \cdot \mathrm{ha}^{-1}$} & \multicolumn{3}{|c|}{$\mathrm{LSD}_{(0.05)}=578 \mathrm{~kg} \cdot \mathrm{ha}^{-1}$} \\
\hline
\end{tabular}

${ }^{1}$ Treatments consist of 3 rates each of 2,4-D + clopyralid $\left(0.28 \mathrm{~kg}\right.$ ai $\cdot \mathrm{ha}^{-1}+0.0532 \mathrm{~kg}$ ai $\cdot \mathrm{ha}^{-1}, 0.56 \mathrm{~kg}$ ai $\cdot \mathrm{ha}^{-1}+0.1064 \mathrm{~kg}^{2} \cdot \mathrm{ha}^{-1}, 0.84 \mathrm{~kg}$ ai $\cdot \mathrm{ha} \mathrm{a}^{-1}+0.1596$

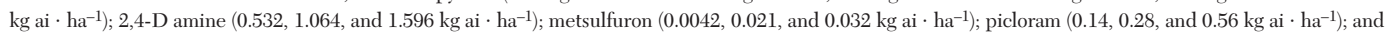
clopyralid $\left(0.05025,0.21\right.$, and $0.42 \mathrm{~kg}$ ai $\left.\cdot \mathrm{ha}^{-1}\right)$. For ease of presentation, the treatments are labeled low, medium, or high rates for each herbicide.

influence medic in 2000. This accounted for the interaction. In both years picloram reduced medic cover at least 7\%. All other herbicides produced similar black medic cover to that of the control at this site.

FORB BIOMASS.-No treatment influenced total or any individual forb biomass at White Buffalo, and total forb biomass was not affected by any treatment at Paddy Creek. Individual species analysis revealed that rates across all herbicides affected cudweed sagewort biomass at Paddy Creek $\left(P=0.05 ; \operatorname{LSD}_{(0.05)}=\right.$ $\left.73 \mathrm{~kg} \cdot \mathrm{ha}^{-1}\right)$. Low herbicide rates increased cudweed sagewort biomass from $50 \mathrm{~kg} \cdot \mathrm{ha}^{-1}$ in the control to $138 \mathrm{~kg} \cdot \mathrm{ha}^{-1}$. Other rate effects were not detected.

FORB DENSITY.-Herbicide affected forb density at White Buffalo $\left(P=0.06\right.$ LSD $_{(0.05)}$ $=47$ plants $\left.\cdot \mathrm{m}^{-2}\right)$. Total forb density was 167 plants $\cdot \mathrm{m}^{-2}$ in the nontreated control. Metsulfuron, picloram, or clopyralid reduced total forbs to 104,98 , and 134 plants $\cdot \mathrm{m}^{-2}$, respectively. Clopyralid plus 2,4-D or 2,4-D alone produced similar forb density to that of the control.

Analysis of individual species forb density detected a herbicide main effect on western yarrow density at White Buffalo $(P=0.03$; $\operatorname{LSD}_{(0.05)}=29$ plants $\left.\cdot \mathrm{m}^{-2}\right)$. Picloram produced similar yarrow density to that of the control. Yarrow density increased from 40 plants $\cdot \mathrm{m}^{-2}$ in the control to 74 plants $\cdot \mathrm{m}^{-2}$ after 2,4 -D was applied. Picloram decreased yarrow density to 19 plants $\cdot \mathrm{m}^{-2}$, which was lower than that produced by $2,4-\mathrm{D}$ (74 plants $\cdot \mathrm{m}^{-2}$ ), clopyralid plus 2 ,4-D $\left(60\right.$ plants $\left.\cdot \mathrm{m}^{-2}\right)$, or clopyralid alone $\left(54\right.$ plants $\left.\cdot \mathrm{m}^{-2}\right)$ at this site.
Many-flowered aster density was influenced by herbicide rate at White Buffalo $(P=0.03$; $\operatorname{LSD}_{(0.05)}=22$ plants $\left.\cdot \mathrm{m}^{-2}\right)$. The density of many-flowered aster was about 84 plants $\cdot \mathrm{m}^{-2}$ in the control. The lowest applied rates, regardless of herbicide, reduced many-flowered aster to 57 plants $\cdot \mathrm{m}^{-2}$. Middle and high rates reduced aster density to 28 and 23 plants $\cdot \mathrm{m}^{-2}$, respectively.

Total forb density was not affected at Paddy Creek. Analysis of individual species forb density indicated an herbicide main effect on American vetch $\left(P=0.04 ; \operatorname{LSD}_{(0.05)}=16\right.$ plants $\left.\cdot \mathrm{m}^{-2}\right)$ and an herbicide by rate interaction on western yarrow $\left(P=0.05 ; \operatorname{LSD}_{(0.05)}=\right.$ 115 plants $\cdot \mathrm{m}^{-2}$ ) density at Paddy Creek. Vetch increased from 5.1 plants $\cdot \mathrm{m}^{-2}$ to 32 plants $\cdot \mathrm{m}^{-2}$ after being treated with clopyralid. Western yarrow density was 104 plants $\cdot \mathrm{m}^{-2}$ in the control. Yarrow density was similar to that of the control for all treatments, but density differed among herbicide by rate combinations. In 2000, 2,4-D at $1.064 \mathrm{~kg}$ ai $\cdot \mathrm{ha}^{-1}$, metsulfuron at $0.0042 \mathrm{~kg}$ ai $\cdot \mathrm{ha}^{-1}$, picloram at 0.14 $\mathrm{kg}$ ai $\cdot \mathrm{ha}^{-1}$, or clopyralid at $0.21 \mathrm{~kg}$ ai $\cdot \mathrm{ha}^{-1}$ produced 208, 189, 153, and 139 yarrow plants . $\mathrm{m}^{-2}$, respectively. Picloram at $0.56 \mathrm{~kg}$ ai $\cdot \mathrm{ha}^{-1}$ decreased yarrow to about 10 plants $\cdot \mathrm{m}^{-2}$ at Paddy Creek.

SPECIES DIVERSITY AND RICHNESS.-Shannon-Weiner diversity was not affected by any treatment or combination of treatments at either site. The influence of herbicides on species richness depended upon their rate of application $\left(P=0.05 ; \operatorname{LSD}_{(0.05)}=3\right)$. The control included 9 species of plants. Richness ranged 
TABLE 3. Herbicide effects on total forb cover and western yarrow cover at White Buffalo.

\begin{tabular}{lcc}
\hline \multirow{2}{*}{ Herbicide } & \multicolumn{2}{c}{ Cover $(\%)$} \\
\cline { 2 - 3 } & $\begin{array}{c}\text { Total indigenous } \\
\text { forbs }\end{array}$ & $\begin{array}{c}\text { Western } \\
\text { yarrow }\end{array}$ \\
\hline Control & 28 & 5 \\
Clopyralid+2,4-D & 31 & 8 \\
2,4-D & 29 & 8 \\
Metsulfuron & 24 & 5 \\
Picloram & 19 & 2 \\
Clopyralid & 22 & 6 \\
& $\operatorname{LSD}_{(0.05)}=6.9 \%$ & $\operatorname{LSD}_{(0.05)}=3.4 \%$ \\
\hline
\end{tabular}

TABLE 4. Interaction of herbicide rate $^{1}$ and year on western yarrow at White Buffalo.

\begin{tabular}{lcc}
\hline & \multicolumn{2}{c}{ Western yarrow cover $(\%)$} \\
\cline { 2 - 3 } Rate & 1999 & 2000 \\
\hline Control & 5 & 4 \\
Low & 6 & 5 \\
Medium & 7 & 6 \\
High & 2 & 7 \\
& $\operatorname{LSD}_{(0.05)}=2.7 \%$ \\
\hline
\end{tabular}

${ }^{1}$ Treatments consist of 3 rates each of 2,4-D + clopyralid $\left(0.28 \mathrm{~kg}\right.$ ai $\cdot \mathrm{ha}^{-1}+$ $0.0532 \mathrm{~kg}$ ai $\cdot \mathrm{ha}^{-1}, 0.56 \mathrm{~kg}$ ai $\cdot \mathrm{ha}^{-1}+0.1064 \mathrm{~kg}$ ai $\cdot \mathrm{ha}^{-1}, 0.84 \mathrm{~kg} \mathrm{a} \cdot \mathrm{ha}^{-1}+$ $0.1596 \mathrm{~kg}$ ai $\left.\cdot \mathrm{ha}^{-1}\right) ; 2,4$-D amine $\left(0.532,1.064\right.$, and $1.596 \mathrm{~kg}$ ai $\left.\cdot \mathrm{ha}^{-1}\right)$; metsulfuron $\left(0.0042,0.021\right.$, and $0.032 \mathrm{~kg}$ ai $\left.\cdot \mathrm{ha}^{-1}\right)$; picloram $(0.14,0.28$, and $0.56 \mathrm{~kg}$ ai $\left.\cdot \mathrm{ha}^{-1}\right)$; and clopyralid $\left(0.05025,0.21\right.$, and $\left.0.42 \mathrm{~kg} \mathrm{ai} \cdot \mathrm{ha}^{-1}\right)$. For ease of presentation, the treatments are labeled low, medium, or high rates for each herbicide.

from about 8 species after picloram was applied at $0.56 \mathrm{~kg}$ ai $\cdot \mathrm{ha}^{-1}$ to 11 species after application of metsulfuron at $0.032 \mathrm{~kg}$ ai $\cdot \mathrm{ha}^{-1}$.

\section{Discussion}

Low species richness and relative abundance of coexisting species is typical in the presence of a highly efficient, nonindigenous invader such as sulfur cinquefoil (Rice 1993, Randall 1996). Based on structural and ecophysiological similarities among forbs and sulfur cinquefoil, we hypothesized that hand-removal of this invader would increase species richness and diversity. Hand-removing sulfur cinquefoil increased the total richness of the sites, and total indigenous forbs were significantly higher in richness and cover. These findings are similar to those of Tyser and Key (1988) for spotted knapweed and Belcher and Wilson (1989) for leafy spurge. However, species diversity weighted by abundance (Shannon-Weiner index) was unaffected by removing sulfur cinquefoil. Hand-removing sulfur cinquefoil did not in-
TABLE 5. Interaction of herbicides and rate on American vetch cover at Paddy Creek.

\begin{tabular}{lccc}
\hline \multirow{2}{*}{ Herbicide } & \multicolumn{3}{c}{ American vetch cover $(\%)$} \\
\cline { 2 - 4 } Control & Low & Medium & High \\
Clopyralid + 2,4-D & 2 & 2 & 2 \\
2,4-D & 2 & 2 & 1 \\
Metsulfuron & 1 & 4 & 3 \\
Picloram & 4 & 2 & 1 \\
Clopyralid & 1 & 1 & 0 \\
& 2 & 1 & 1 \\
\hline
\end{tabular}

crease grass richness, density, or production after 2 seasons. We speculate that forbs may have benefited more from increased resource availability resulting from invader removal than grasses because forbs may occupy niches similar to that of sulfur cinquefoil (Sheley et al. 1996, Pokorny 2002).

Forbs are essential components of plant communities because they provide structure and function central to ecosystem sustainability (Pokorny 2002). Pokorny (2002) emphasized the importance of considering indigenous forbs, because of their abundance, when making invasive plant management decisions. Forbs may also be critical because they preempt resource use by weedy species and provide a barrier to invasion (Pokorny 2002). In this study species richness and diversity were not affected by any herbicide treatment, similar to results found by Rice et al. (1997). However, picloram reduced forb cover below that of the control at both sites regardless of rate. In addition, picloram, metsulfuron, and clopyralid reduced total forb density at White Buffalo. Loss of important forbs may open niches and create safe sites for nonindigenous invasion (Levine and D'Antonio 1999, Dukes 2001, Pokorny 2002).

The limited impact of 2,4-D is consistent with Jacobs and Sheley's (1999a) findings that 2,4-D can be applied at a phenological stage that will minimally affect total forb production. Since 2,4-D is somewhat effective in controlling sulfur cinquefoil and spotted knapweed when applied later in the growing season, controlling these invaders while maintaining competitive forbs may reduce reinvasion. Increased niche occupation is believed to be a critical element necessary for native communities to enhance their resource capture and preempt acquisition by an invader (Pyke and Archer 1991, Tilman 1996, Jacobs and Sheley 1999b). 
From a cultural and medicinal perspective, certain individual species are also important when considering the influence of herbicides on plant community composition. Western yarrow and cudweed sagewort were affected by various herbicides. High rates of any herbicide decreased cover and, in many cases, density of yarrow below that of the low or medium rate of herbicides at White Buffalo. By the second year, this species' cover fully recovered. This species was also sensitive to high rates of herbicides in a study conducted in western Montana (Rice and Toney 1996). Interestingly, low herbicide rates increased cudweed sagewort biomass at Paddy Creek.

In this rangeland herbicide study, we hypothesized that species would respond independently to different herbicides and their rate of application, with graminoid species capitalizing most on available site resources (Pechanec et al. 1965, Rice et al. 1997, Jacobs and Sheley 1999c). As expected, the perennial grass group increased in cover and biomass at both White Buffalo and Paddy Creek over the 2 years. Herbicides that increased grass cover and biomass were different depending on site. Our results suggest that the grass species response depended upon site and herbicide treatments. Therefore, managers must consider all species in a community before selecting a herbicide (Sheley et al. 1996, Jacobs and Sheley 1999c).

Herbicides can be very effective in increasing grass production (Dahl et al. 1989). Perennial grass cover and biomass increased following herbicide application. In many cases herbicides more than doubled perennial grass production 2 years after herbicide treatment. This shift toward grasses may have occurred, in part, because of the increase in resources available after forb control. Most earlier studies focused on controlling indigenous forbs for increased grass production (Blaisdell and Mueggler 1956, Laycock and Phillips 1968, Tabler 1968, Schumaker and Hanson 1977, Miller et al. 1980). Increasing grass production by controlling both indigenous and nonindigenous species is currently a major focus of invasive plant management (Sheley and Petroff 1999). We believe that weed management must focus on restoring function and structure of the plant community, rather than simply controlling weeds for grass production (Sheley et al 1996).
Improvement in range condition is typically a desirable outcome for range managers (Dyksterhuis 1949). To improve condition, those species that decrease with grazing must recover and substantially increase in relative abundance. On our sites improvement in range condition did not occur because many of the key decreaser species were no longer present. In fact, the use of herbicides, picloram in particular, allowed increased abundance of Kentucky bluegrass and shifted the community composition further away from the potential natural community at Paddy Creek (Mueggler and Stewart 1980).

\section{Literature Cited}

BELCHER, J.W., AND S.D. Wilson. 1989. Leafy spurge and the species commotion of a mixed grass prairie. Journal of Range Management 42:172-175.

Blaisdell, J.P., AND W.F. MEugGLER. 1956. Effects of 2,4-D on forbs and shrubs associated with big sagebrush. Journal of Range Management 9:38-40.

CudA, J.P., B.W. SindELAR, AND J.H. CARDELLINA II. 1989. Proposal for an integrated management system for spotted knapweed (Centaurea maculosa Lam.). Pages 197-203 in P.K. Fay and J.R. Lacey, editors, Knapweed symposium proceedings EB45. Plant \& Soil Department and Extension Service, Montana State University, Bozeman.

Dahl, B.E., J.C. Mosley, P.F. CotTer, and R.L. DiCKerson, JR. 1989. Winter forb control for increased grass yield on sandy rangeland. Journal of Range Management 42:400-403.

Dukes, J. 2001. Biodiversity and invasibility in grassland microcosms. Oecologia 126:563-568.

Dyksterhuis, E.J. 1949. Condition and management of rangeland based on quantitative ecology. Journal of Range Management 2:104-115.

ELton, C.S. 1958. The ecology of invasions by animals and plants. University of Chicago Press, Chicago, IL.

Griffith, D., AND J.R. LACEY. 1991. Economic evaluation of spotted knapweed (Centaurea maculosa) control using picloram. Journal of Range Management 44: 42-44.

Hamaker, J.W., C.R. Youngson, and G.A. Goring. 1967. Predictions of the persistence and activity of Tordon herbicide in soils under field conditions. Down to Earth 23:30-36.

Harris, P., AND R. Cranston. 1979. An economic evaluation of control methods for diffuse and spotted knapweed in western Canada. Canadian Journal of Plant Science 59:375-382.

JACOBS, J.S., AND R.L. Sheley. 1999a. Spotted knapweed, forb, and grass response to 2,4-D and N-fertilizer. Journal of Range Management 52:482-488.

1999b. Competition and niche partitioning among Pseudoroegneria spicata, Hedysarum boreale, and Centaurea maculosa. Great Basin Naturalist 59: 175-181.

. 1999c. Grass defoliation intensity, frequency, and season effects on spotted knapweed invasion. Journal of Range Management 52:626-632. 
Kedzie-Webb, S.A., R.L. Sheley, J.J. Borkowski, And J.S. JACOBS. 2001. Relationships between Centaurea maculosa and indigenous plant assemblages. Western North American Naturalist 61:43-49.

LaCEY, J.R., C.B. Marlow, and J.R. Lane. 1989. Influence of spotted knapweed (Centaurea maculosa) on surface runoff and sediment yield. Weed Technology 3:627-631.

LAYCOCK, W.A., AND T.A. PhiLLIPS. 1968. Long-term effects of 2,4-D on lanceleaf rabbitbrush and associated species. Journal of Range Management 21:90-93.

Levine, J.M., AND C.M. D’AnTonio. 1999. Elton revisited: a review of the evidence linking diversity and invasibility. Oikos 87:15-26.

LocKwOOD, J.L. 1997. An alternative to succession: assembly rules offer guide to restoration efforts. Restoration and Management Notes 15(1):45-51.

Miller, R.F., R.R. Findley, And J. Alderfer-Findley. 1980. Changes in mountain big sagebrush habitat types following spray release. Journal of Range Management 33:273-281.

Mueggler, W.F., and W.L. Stewart. 1980. Grassland and shrubland habitat types of western Montana. USDA Forest Service, Intermountain Forest and Range Experiment Station, Ogden, UT.

Pechanec, J.F., A.P. Plummer, J.H. Robertson, and A.C. Hull, JR. 1965. Sagebrush control on rangelands. USDA Agricultural handbook 277. Washington, DC.

Peterson, R.G. 1985. Design and analysis of experiments. Marcel Dekker, Inc., New York.

PoKorny, M.L. 2002. Plant functional group diversity as a mechanism for invasion resistence. Master's thesis, Montana State University, Bozeman.

Pyke, D.A., AND S. ARChER. 1991. Plant-plant interactions affecting plant establishment and persistence on revegetated rangeland. Journal of Range Management 44:550-557.

RANDALL, J.M. 1996. Weed control for the preservation of biological diversity. Weed Technology 10:370-383.

RejmaneK, M. 1996. A theory of seed plant invasiveness: the first sketch. Biological Conservation 78:171-181.

Rice, P.M. 1993. Distribution and ecology of sulfur cinquefoil in Montana, Idaho and Wyoming. Final report. Montana Department of Agriculture, Helena.
Rice, P.M., AND J.C. Toney. 1996. Plant population responses to broadcast herbicide applications for spotted knapweed control. Down to Earth 51:14-19.

Rice, P.M., J.C. Toney, D.J. Bedunah, and C.E. CarlSON. 1997. Plant community diversity and growth form responses to herbicide applications for control of Centaurea maculosa. Journal of Applied Ecology 34:1397-1412.

SAS InstiTUTE, INC. 1990. SAS/STAT user's guide, version 6. Volume 2. Cary, NC.

Schumaker, G.A., and C.L. Hanson. 1977. Herbage response after mechanical and herbicide treatment of big sagebrush in southwest Idaho. USDA Agriculture Research Service w- 46.

Sheley, R.L., And J.K. Petroff, Editors. 1999. The biology and management of noxious rangeland weeds. Oregon State University Press, Corvallis.

Sheley, R.L., T.J. SvejCar, and B.D. Maxwell. 1996. A theoretical framework for developing successional weed management strategies on rangeland. Weed Technology 10:766-773.

TABLER, R.D. 1968. Soil moisture response to spraying big sagebrush with 2,4-D. Journal of Range Management 21:12-15.

Tilman, D. 1996. Biodiversity: population versus ecosystem stability. Ecology 77:350-363.

USDA-NRCS. 1996. Soil survey of Rosebud County area and part of Bighorn County, Montana.

Tyser, R.W., AND C.H. Key. 1988. Spotted knapweed in natural area fescue grasslands: an ecological assessment. Northwest Science 62:981-987.

Vitousek, P.M. 1986. Biological invasions and ecosystem properties: can species make a difference? Pages 163-176 in J.A. Mooney and J.A. Drake, editors, Ecology of biological invasions in North America and Hawaii. Springer-Verlag, New York.

Vitousek, P.M., AND L.R. WALKer. 1986. Biological invasions by Myrica faya in Hawaii: plant demography, nitrogen fixation, ecosystem effects. Ecological Monographs 59:247-265.

Received 22 January 2004 Accepted 22 March 2005 